\title{
Seroprevalence and seroconversion rates to SARS-CoV-2 in interns, residents, and medical doctors in a University Hospital in Bogotá, Colombia
}

Beatriz Ariza ${ }^{2}$, Ximena Torres ${ }^{1}$, Diana Salgado ${ }^{3}$, Magda Cepeda ${ }^{6}$, Carlos Gómez Restrepo ${ }^{5,6}$, Julio Cesar Castellanos ${ }^{5}$, Fernando Suárez-Obando ${ }^{1}$, Adriana Cuellar ${ }^{4}$, Claudia Cardozo ${ }^{3}$, Juana Ángel ${ }^{1}$, and Manuel Antonio Franco ${ }^{1 *}$

${ }^{1}$ Instituto de Genética Humana, Facultad de Medicina, Pontificia Universidad Javeriana, Bogotá, Colombia

${ }^{2}$ Infectious Diseases Research group, Clinical Laboratory, Hospital Universitario San Ignacio, Bogotá Colombia

${ }^{3}$ Clinical Laboratory Science Research group, Clinical Laboratory, Hospital Universitario San Ignacio, Bogotá Colombia

${ }^{4}$ Clinical Laboratory Science Research group, Department of Microbiology, School of Science, Pontificia Universidad Javeriana, Bogotá, Colombia

${ }^{5}$ Hospital Universitario San Ignacio, Bogotá Colombia

${ }^{6}$ Department of Clinical Epidemiology and Biostatistics, Facultad de Medicina, Pontificia Universidad Javeriana, Bogotá, Colombia

* Corresponding author 
medRxiv preprint doi: https://doi.org/10.1101/2020.09.15.20195313; this version posted September 18, 2020. The copyright holder for this preprint (which was not certified by peer review) is the author/funder, who has granted medRxiv a license to display the preprint in perpetuity.

It is made available under a CC-BY-NC-ND 4.0 International license .

Full name: Manuel Antonio FRANCO

Department: Instituto de Genética Humana

Institute/University/Hospital

Street Name \& Number: Carrera 7 No. 40-62

City, State, Postal code, Country: Bogotá, Colombia

Tel: 57-1-3208320 ext. 2790

E-mail: mafranco@javeriana.edu.co

Key Words: COVID-19; SARS-CoV-2; seroprevalence, seroconversion rate; health care workers. 


\section{Highlights}

Latin America was one of the most severely compromised regions of the world during the SARS-CoV-2 pandemic, between June and August 2020.

Healthcare workers are at increased risk for COVID-19 and studies of seroprevalence and seroconversion rates in these subjects have not been published in the area.

We conducted a cross-sectional and prospective study of medical doctors and medical trainees in a University Hosptial during June, July, and August 2020 to assess seroprevalence and seroconversion rates of SARS-CoV-2 in this population, using a Chemiluminescent assay (CLA).

At baseline, $8(2.28 \% 95 \% \mathrm{Cl} 1.16-4.43 \%)$ individuals were IgG positive for SARS-CoV2 by CLA. At the end of the study, $21(5.98 \% 95 \% \mathrm{Cl} 3.94-8.97 \%)$ individuals had seroconverted by CLA IgG.

In all, 29 (8.26\% 95\%Cl 5.81-11.61\%) individuals had IgG for SARS-CoV-2 by CLA and of these $11(3.13 \% 95 \% \mathrm{Cl} 1.76-5.52 \%)$ were asymptomatic. 


\section{Abstract}

Objectives

To determine the prevalence of antibodies to SARS-CoV-2 and the incidence of seroconversion in the first month of follow-up among interns, residents, and medical doctors attending patients at a University Hospital, to explore for associations of seroprevalence and seroconversion with risk factors and symptoms compatible with COVID-19, and to explore the concordance of CLA, LFA, and ELFA.

Design or methods

We conducted a cross-sectional and a prospective study among medical doctors and medical trainees at Hospital Universitario San Ignacio in Bogota (Colombia) during June, July, and August to assess seroprevalence and seroconversion rates in this population was performed using CLA IgG for SARS-CoV-2. LFA IgG and IgM and ELFA $\lg M$ were also determined to explore concordance with CLA IgG.

Results

At baseline, $8(2.28 \% 95 \% \mathrm{Cl} 1.16-4.43 \%)$ individuals were IgG positive for SARS-CoV2 by CLA. At the end of the study, $21(5.98 \% 95 \% \mathrm{Cl} 3.94-8.97 \%)$ individuals seroconverted by CLA IgG. In all, 29 individuals had IgG by CLA and of these 11 $(3.13 \% 95 \% \mathrm{Cl} 1.76-5.52 \%)$ were asymptomatic. No associations with risk factors for infection were identified. CLA had moderate concordance with LFA IgG and ELFA, but minimal with LFA IgM. 
medRxiv preprint doi: https://doi.org/10.1101/2020.09.15.20195313; this version posted September 18, 2020. The copyright holder for this preprint (which was not certified by peer review) is the author/funder, who has granted medRxiv a license to display the preprint in perpetuity. It is made available under a CC-BY-NC-ND 4.0 International license.

\section{Conclusions}

Our report is one of the first in Latina America on seroprevalence and seroconversion rates in medical healthcare workers. It emphasizes the importance of avoiding focusing only on symptomatic individuals to screen this population for SARS-CoV-2 infection, since of all individuals that have evidence of previous infection many $(37.93 \%)$ may be pre-symptomatic or asymptomatic and may contribute to infection/disease spread. 
medRxiv preprint doi: https://doi.org/10.1101/2020.09.15.20195313; this version posted September 18, 2020. The copyright holder for this preprint (which was not certified by peer review) is the author/funder, who has granted medRxiv a license to display the preprint in perpetuity.

It is made available under a CC-BY-NC-ND 4.0 International license.

\section{Introduction}

During the SARS-CoV-2 pandemic healthcare workers (HCW) have been shown to have an increased risk of infection [1-6]. Studies in this population in many parts of the world have shown seroprevalences of between $2.4 \%$ and $45 \%$, and in general above that of the general population and varing according to multiple factors [1-6]. In asymptomatic HCW, at the peak of the pandemic in England, a global seroprevalence rate of $24.4 \%$ was found [7]. Furthermore, individuals who retrospectively reported symptoms compatible with COVID-19 had a higher seroprevalence rate than those who did not report them, in this study and other studies [6,7]. Although retrospective reporting of symptoms may have evocation bias, these findings indicates that, in the context of COVID-19 a relationship can be established between retrospectively reported symptoms and seroprevalence. Seroconversion rates in HCW have been reported in fewer studies and varied between $20-44 \%$ in short term followup during high circulation of SARS-CoV-2 [1,8].

Latin-America is one of the most affected regions of the world by the pandemic [9], with peak cases occurring between July 20 and August 16 [10]. Although some studies from Latin-American countries evaluating serology in the general population [11,12] or schools have been published $[13,14]$, to our knowledge only one study in an oncology unit in Brazil [15] has assessed seroprevalence in HCW. Our study was performed during a very active increase of SARS-CoV-2 infections in our country and city: during the five weeks of the study 248,205 new cases were identified in Colombia $(109,505$ vs. $357,710)$ and 93,907 of these were in Bogotá $(34,131$ vs. 128,038) 
medRxiv preprint doi: https://doi.org/10.1101/2020.09.15.20195313; this version posted September 18, 2020. The copyright holder for this preprint (which was not certified by peer review) is the author/funder, who has granted medRxiv a license to display the preprint in perpetuity.

It is made available under a CC-BY-NC-ND 4.0 International license .

(http://saludata.saludcapital.gov.co/osb/index.php/datos-de-salud/enfermedades-

trasmisibles/covid19/ page consulted 08/19/20). Records from our hospital (Hospital Universitario San Ignacio (HUSI)) show that during June-August the adult intensive care unit (28 beds in June and 32 beds in July and August) was at full (100\%) occupancy with presumed or confirmed COVID-19 patients.

The main purpose of this study was to determine the prevalence of antibodies, and the seroconversion rates to SARS-CoV-2 in a month of follow-up of interns, residents, and medical doctors of the School of Medicine of the Pontificia Universidad Javeriana attending patients at $\mathrm{HUSI}$.

\section{Methods:}

A) Study design:

First, a cross-sectional study was conducted to determine the seroprevalence of SARS-CoV-2 infection in study population (interns, residents, and medical doctors that were treating patients at HUSI at the time of the study). Potential candidates were invited to participate by email. Potential participants who were not attending patients at HUSI in June and July and who were taking immunosuppressive drugs (chloroquine, corticosteroids, etc.) were excluded from the study (Figure 1). The remaining participants were asked to fill out a survey about risk factors and symptoms associated with COVID-19, history of previous diagnosis of COVID-19 confirmed by PCR or of clinically diagnosed COVID-19 supported by the presence of 
SARS-CoV-2 antibodies. The survey was designed in RedCap (Research Electronico Data capture [16]).

In a second step, a prospective study was conducted to determine the incidence of seroconversion two weeks and a month of follow-up after baseline visit among the seronegative individuals from the cross-sectional study.

As secondary objectives, we aimed to assess the relation between seropositivity either at baseline or during follow-up and risk factors and symptoms compatible with COVID19. Finally, as an exploratory objective, we examined the concordance of CLA IgG as a tempative gold standard with the LFA IgG and IgM and ELFA IgM and concordance of the ELFA IgM and LFA IgM.

B) Sampling and laboratory methods:

At the HUSl's clinical laboratory, individuals updated the survey of clinical symptoms compatible with COVID-19, signed an electronic informed consent, and donated $7 \mathrm{ml}$ of venous blood.

Chemiluminescent assay (CLA)

SARS-CoV-2 IgG tests (Abbott Colombia) were performed on an Abbott Architect i1000 analyzer, following the manufacturer's protocol. A single lot of positive and negative controls were run at the start of each batch of antibody testing. Samples with a signalto-cutoff $(\mathrm{S} / \mathrm{CO})$ ratio greater than or equal to 1.4 were considered positive. 
SARS-CoV-2 STANDARD Q COVID-19 IgM/lgG Duo Test kits (SD Biosensor, Gyeonggi-do, Korea) were performed following the manufacturer's protocols. Positive results were determined by the appearance of a visible band in the designated area, simultaneously with an appropriate positive control band.

Enzyme linked fluorescence assay (ELFA)

The VIDAS Anti-SARS CoV-2 IgM two-step sandwich ELFA was performed on a VIDAS analyzer (BioMérieux, Marcy-l'Etoile, France). An index is calculated as the ratio between the relative fluorescence value measured in the sample and the relative fluorescence obtained for a calibrator (humanized recombinant anti-SARS CoV-2 IgM) and interpreted as negative (index $<1$ ) or positive (index $\geq 1$ ) [17].

All assays were validated with serum samples from PCR+/- individuals in our laboratory

\section{Ethical considerations}

Our project complied with the legal and ethical guidelines contemplated in the Declaration of Helsinki of the World Medical Association, Fortaleza, Brazil, 2013. Likewise, it adheres to the ethical considerations outlined in articles 15 and 16 of Resolution No. 008430 of 1993 of the Ministry of Health and in Law 84 of 1989. The study and the informed consent form were approved by the ethics committee of School of Medicine of the Pontificia Universidad Javeriana and HUSI. 


\section{Statistical analysis:}

The data was exported and analyzed in Stata 14. We conducted a descriptive analysis of the demographic characteristics of the study participants, according to the seropositivity. Continuous variables were described using median and interquartile range (percentiles 25th and 75th) and categorical variables were described using absolute and relative frequencies.

Second, we examined the relation between seropositivity either at baseline or during the follow-up and risk factors and symptoms compatible with COVID-19, we estimated the odds ratio and $95 \%$ confidence interval using logistic regression

Third, we assessed the concordance of CLA IgG, as a tempative gold standard, with LFA IgG and IgM and ELFA IgM, and the concordance of ELFA IgM and LFA IgM, using the Cohen's kappa and the corresponding 95\% confidence interval.

\section{Results}

\section{Study population:}

Seven hundred and fifty-two (752) medical trainees or medical doctors from HUSI were invited to participate by email (Figure 1). Of these, 428 answered the baseline survey, and it was possible to arrange an appointment to bleed 351 of them (Figure 1). Six individuals reported a previous diagnosis of infection with SARS-CoV-2 confirmed by PCR (all but one with symptoms compatible with COVID-19) and two had been hospitalized with symptoms consistent with COVID-19 and positive SARS-CoV-2 
medRxiv preprint doi: https://doi.org/10.1101/2020.09.15.20195313; this version posted September 18, 2020. The copyright holder for this preprint (which was not certified by peer review) is the author/funder, who has granted medRxiv a license to display the preprint in perpetuity.

It is made available under a CC-BY-NC-ND 4.0 International license .

antibodies, but their PCR had not identified SARS-CoV-2 (Tables 1 and 2 and Data not shown).

\section{Prevalence of SARS-CoV-2 antibodies in our cohort at baseline}

Individuals in our cohort were bled at baseline between June 25 and the 4 of July. At baseline $8(2.28 \% 95 \% \mathrm{Cl} 1.16-4.43 \%)$ individuals were SARS-CoV-2 IgG positive by CLA (Table 1 and Figure 2). For comparison, we also measured IgG and IgM antibodies by LFA (Table 1) and found that six individuals of the eight indivuals were also positive for IgM and IgG by LFA. Of these six individuals, one had COVID-19 compatible symptoms and a previous diagnosis of COVID-19 by PCR, two had previously been hospitalized with clinical diagnosis of COVID-19 (with negative PCR but positive serology), one had a positive PCR but had remained asymptomatic, and two without history of previous SARS-CoV-2 infection were also asymptomatic (Tables 1 and 2). Finally, one asymptomatic and one symptomatic individual were positive for lgG by CLA, but negative for LFA antibodies (Table 2). In addition, 18 individuals were only positive for SARS-CoV-2 LFA IgM and one was only positive for LFA IgG (Table 1). One

of the 18 individuals that was only positive for IgM had a history of previous COVID-19 symptoms and a positive PCR before joining the study (Tables 1 and 2). The majority of individuals (16/18) with only a positive LFA IgM result and tested for SARS-CoV-2 PCR were negative for PCR at a date close to the date when the antibody sample was obtained (Table 2). Somewhat unexpectedly, three of the eight individuals that declared having a positive SARS-CoV-2 PCR previous to the start of the study were negative for all of the antibodies measured (Data not shown). 
medRxiv preprint doi: https://doi.org/10.1101/2020.09.15.20195313; this version posted September 18, 2020. The copyright holder for this preprint (which was not certified by peer review) is the author/funder, who has granted medRxiv a license to display the preprint in perpetuity.

It is made available under a CC-BY-NC-ND 4.0 International license.

\section{Incidence of SARS-CoV-2 antibodies}

A second and third blood samples was taken approximately two weeks (15.1 days $95 \% \mathrm{Cl} 14.8-15.4)$ and one month (28.7 days $95 \% \mathrm{Cl} 28.3-29.0)$ after baseline for each individual, from the 9th-21st of June and from June 23 to August 10, respectively.

Three hundred and thirty-five (335) of the original 351 (95.4\%) individuals presented for the second bleeding. All eight initially positive individuals by CLA IgG remained positive (Table 1). Of the remaining 327 individuals, nine seroconverted in SARS-CoV-2 CLA $\operatorname{lgG}(2.75 \% 95 \% \mathrm{Cl} 1.45-5.14 \%$, Table 1 and Figure 2). Three of these nine individuals were asymptomatic. None of the previously IgM positive individuals by LFA or the individual that only was $\lg$ G positive by LFA seroconverted by CLA IgG (Table 1) in the second bleed.

Three hundred and thirty-nine (339) of the original 351 (96.5\%) individuals presented for the third bleeding. Seven of eight initially IgG positive individuals by CLA remained positive (Table 1), with one individual scoring marginally below the cutoff level of the assay (Figure 2). All nine individuals that seroconverted in IgG CLA in the second bleed remained positive and 12 new individuals $(3.93 \% 95 \% \mathrm{Cl} 2.31-6.61 \%)$ seroconverted. Four of the twelve individuals that seroconverted in the last sample were asymptomatic (Table 1). None of the previously IgM positive individuals by LFA or the individual that only was IgG positive by LFA seroconverted by CLA (Table 1) in the third bleed. Altogether, we identified 21 individuals $(5.98 \% 95 \% \mathrm{Cl} 3.94-8.97 \%)$ that seroconverted to SARS-CoV-2 IgG by CLA amongst our initial cohort of 351 individuals (Table 1 and Figure 2). Thus, adding the 21 individuals that seroconverted with the eight that had IgG 
medRxiv preprint doi: https://doi.org/10.1101/2020.09.15.20195313; this version posted September 18, 2020. The copyright holder for this preprint (which was not certified by peer review) is the author/funder, who has granted medRxiv a license to display the preprint in perpetuity.

It is made available under a CC-BY-NC-ND 4.0 International license .

by CLA at baseline, 29 individuals $(8.26$ 95\% $5.81-11.61 \%)$ had SARS-CoV-2 IgG by CLA and of these $11(3.13 \% 95 \% \mathrm{Cl} 1.76-5.52 \%)$ were asymptomatic (Table 1).

Associations of seroprevalence and seroconversion with risk factors and symptoms compatible with COVID-19

Demographic, infection risk factors, and prevalence of symptoms compatible with COVID-19 for this population are presented in Table 3 for individuals with or without a positive SARS-CoV-2 CLA test in the study. No risk factors were associated with seroprevalence or seroconversion to SARS-CoV-2.

\section{Concordance of the antibody assays}

To further evaluate concordance of the LFA and CLA assays and to extend this analysis

to ELFA IgM, thawed samples from the first bleed were tested by ELFA and thawed samples from bleeds 2 and 3 were tested by ELFA IgM and LFA IgG and IgM. Concordance of CLA IgG with LFA IgG and ELFA IgG was moderate and with LFA IgM, minimal (Table 4) [18]. The ELFA IgM and LFA IgM also had minimal concordance (Table 5).

\section{Discussion}

We have performed one of the first SARS-CoV-2 seroprevalence/seroconversion rate studies in Latin-America and found that at baseline $2.28 \%$ of HCW were IgG positive by CLA (Table 1). At the end of the study, $5.98 \%$ of individuals had seroconverted by CLA 
medRxiv preprint doi: https://doi.org/10.1101/2020.09.15.20195313; this version posted September 18, 2020. The copyright holder for this preprint (which was not certified by peer review) is the author/funder, who has granted medRxiv a license to display the preprint in perpetuity.

It is made available under a CC-BY-NC-ND 4.0 International license .

$\lg$ and, in all, 29 individuals (8.26\%) had SARS-CoV-2 IgG by CLA, of which 11 (3.13\%) were asymptomatic (Table 1). No associations between seroprevalence/seroconversion in CLA and risk factors for infection were identified. Concordance of CLA IgG with LFA IgG and ELFA IgG was moderate and with LFA IgM, minimal (Table 4). The ELFA IgM and LFA IgM also had minimal concordance (Table 5).

The levels of seroprevalence for CLA IgG (2.28\%) at the beginning of the study and of seroconversion to this antibody (5.98\%) are comparable to those reported in other studies and, overall, higher than those observed in the general population [1-6]. In a comparable study in England that followed 200 front line HCW for two weeks, they found that $20 \%$ of them seroconverted during the study, but $25 \%$ were already seropositive at the beginning of the study [1]. Most likely, the higher numbers in the English study compared with our study are due to the differences in the populations studied (front line workers vs a mixed population of medical doctors).

One of the main findings of our study, is the relatively high numbers $(3.18 \%)$ of asymptomatic individuals positive for IgG by CLA (Table 1). This number is very close to the number of asymptomatic HCW detected by screening with PCR in nasofaringeal swabs (3\%) [19] or saliva (2,6\%) [20] in England. Although it is incompletely clear how much pre-symptomatic and asymptomatic individuals contribute to virus spread, focusing only on stopping symptomatic individuals is insufficient to control the spread of the virus [21,22]. None-invasive rapid screening strategies for SARS-CoV-2 infection are needed to evaluate symptomatic and asymptomatic HCW. 
medRxiv preprint doi: https://doi.org/10.1101/2020.09.15.20195313; this version posted September 18, 2020. The copyright holder for this preprint (which was not certified by peer review) is the author/funder, who has granted medRxiv a license to display the preprint in perpetuity.

It is made available under a CC-BY-NC-ND 4.0 International license .

The lack of association between risk factors and SARS-CoV-2 seroprevalence/seroconversion in CLA (Table 3) may be explained because some of the risk factors evaluated (obesity, diabetes, hypertension, and smoking) can be risk factors for disease and not infection. Moreover, most of the participants used PPE and followed biosafety recommendations (Table 3).

Our results seem comparable to previous studies in which the CLA test that we used showed a sensitivity and specificity close to $100 \%$ when compared with PCR +/samples [23-25], while the LFA [26] and the ELFA [17] appear to be less sensitive and specific. The LFA IgG seems to have missed 20 samples positive by CLA IgG (Tabel 4), and all but one of the 11 samples positive by LFA IgG but negative by CLA IgG were only positive for this antibody, suggesting they may be false positives. The minimal concordance of the LFA IgM with other assays can probably be explained because of a high level of false positives: at baseline most $(18,5.13 \% 95 \% \mathrm{Cl} 3.27-7.96)$ of the individuals that had any positive antibody were positive for LFA IgM only (Table 1). However, none of these individuals had a positive PCR at or close to the time when the sample was taken (Table 3). With few exceptions, they did not present with COVID-19 compatible symptoms (Table 1) and none of them seroconverted to IgG by CLA on follow-up. These results are consistent with the hypothesis that most, if not all, of these results are false-positive results. This hypothesis is in agreement with the validation performed by our National Institute of Health that reports that the IgM LFA assay may have $4 \%$ false positives defined using serums from prepandemic individuals (https://www.ins.gov.co/Pruebas Rapidas/4.\%20Informe\%20de\%20validaci\%C3\%B3n \%20PR\%20SD\%20Biosensor.pdf page consulted August 25). 
Our study may have a sampling bias. Independent data from our hospital indicate that up to the 15th of June 13 medical doctors and 7 residents from approximately 800 individuals had been diagnosed with COVID-19 (with PCR or clinical symptoms/serology). By the $15^{\text {th }}$ of August, these numbers had increased to 44 medical doctors and 55 residents diagnosed with COVID-19. These numbers are higher than what we found in our population an suggest that our values of seroprevalence and seroconversion may be underestimated. A probable explanation for this is that volunteers with COVID-19 were isolated at the time of sampling and were unable to participate in the study or that having been previously tested were uninterested in participating.

\section{Statements}

\section{Acknowledgement}

We want to thank the volunteers that participated and donated blood for this study. We want to thank Dr Pablo Aschner for careful reading and suggestion for the project and Madga Alba and Jenny Severiche for help with the process of recruiting volunteer.

\section{Ethical Statement}

This study was approved by the Ethics Committee of the School of Medicine of Pontificia Universidad Javeriana Bogotá, Colombia and was done in accordance with 
The Code of Ethics of the World Medical Association (Declaration of Helsinki). An

informed consent form, approved by the Ethics Committee of HUSI and the Pontificia Universidad Javeriana School of Medicine, was signed by all volunteers.

\section{Disclosure Statement}

The authors have no conflicts of interest to declare.

\section{Funding Sources}

This study was funded by Pontificia Universidad Javeriana, Hospital Universitario San Ignacio, and Fundación Bolívar Davivienda. 


\section{Author Contributions}

Juana Angel AND Manuel Franco: Conceptualization; Data curation; Formal analysis; Funding acquisition; Project administration; Resources; Supervision; Writing - original draft; Writing - review \& editing.

Ximena Torres and Diana Salgado: Data curation; Investigation; Writing - review \& editing.

Beatriz Ayala: Conceptualization; Project administration; Investigation; Supervision; Writing - review \& editing.

Claudia Cardozo: Conceptualization; Resources; Writing - review \& editing.

Magda Cepeda: Conceptualization; Data curation; Software; Formal analysis; Writing review \& editing.

Adriana Cuellar, Fernando Suarez, Carlos Gómez-Restrepo, Julio Cesar Castellanos:

Conceptualization; Writing - review \& editing. 
medRxiv preprint doi: https://doi.org/10.1101/2020.09.15.20195313; this version posted September 18, 2020. The copyright holder for this preprint (which was not certified by peer review) is the author/funder, who has granted medRxiv a license to display the preprint in perpetuity.

It is made available under a CC-BY-NC-ND 4.0 International license .

Figure Legends:

Figure 1. Study Flowchart

Figure 2. SARS-CoV-2 IgG CLA values at different times of blood sampling. Sample 1 was the baseline. Sample 2 was taken 15.1 days $(95 \% \mathrm{Cl} 14.8-15.4)$ days after baseline. Sample 3 was taken 28.7 days $(95 \% \mathrm{Cl} 28.3-29.0)$ after baseline. CLA; Chemiluminescence assay. 
medRxiv preprint doi: https://doi.org/10.1101/2020.09.15.20195313; this version posted September 18, 2020. The copyright holder for this preprint (which was not certified by peer review) is the author/funder, who has granted medRxiv a license to display the preprint in perpetuity.

It is made available under a CC-BY-NC-ND 4.0 International license .

Table 1 Antibodies and symptoms of participants with at least one positive antibody results at baseline.

\begin{tabular}{|c|c|c|c|c|c|c|c|c|c|c|c|c|}
\hline & \multicolumn{5}{|c|}{ Sample 1} & \multicolumn{3}{|c|}{ Sample 2} & \multicolumn{3}{|c|}{ Sample 3} & \\
\hline Volunteer & Date & Symptoms* & IgM LFA & IgG LFA & IgG CLA & Date & Symptoms* & IgG CLA & Date & Symptoms* & IgG CLA & \multirow{9}{*}{ 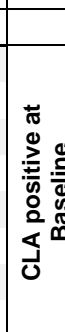 } \\
\hline 1 & Jul 04 & NO & + & + & + & Jul 21 & NO & + & Aug 05 & $\mathrm{NO}$ & - & \\
\hline 2 & Jul 03 & NO & + & + & + & Jul 17 & NO & + & Aug 01 & NO & + & \\
\hline 3 & Jun 25 & NO & + & + & + & Jul 09 & NO & + & Jul 23 & NO & + & \\
\hline 4 & Jun 30 & NO & - & - & + & Jul 16 & NO & + & Jul 30 & $\mathrm{NO}$ & + & \\
\hline 5 & Jul 01 & YES & + & + & + & Jul 15 & NO & + & Jul 29 & NO & + & \\
\hline 6 & Jul 04 & YES & + & + & + & Jul 18 & $\mathrm{NO}$ & + & Aug 01 & NO & + & \\
\hline 7 & Jul 02 & YES & + & + & + & Jul 16 & NO & + & Jul 30 & NO & + & \\
\hline 8 & Jun 30 & YES & - & - & + & Jul 14 & NO & + & Jul 28 & NO & + & \\
\hline 9 & Jun 27 & $\mathrm{NO}$ & - & + & - & Jul 11 & $\mathrm{NO}$ & - & Jul 25 & $\mathrm{NO}$ & - & \multirow{19}{*}{ 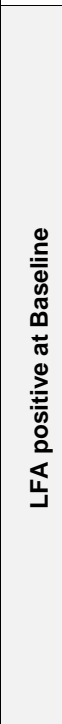 } \\
\hline 10 & Jun 25 & NO & + & - & - & Jul 10 & NO & - & Jul 24 & NO & - & \\
\hline 11 & Jul 03 & NO & + & - & - & Jul 17 & NO & - & Jul 31 & NO & - & \\
\hline 12 & Jun 25 & NO & + & - & - & Jul 09 & NO & - & Jul 23 & NO & - & \\
\hline 13 & Jul 04 & NO & + & - & - & Jul 21 & NO & - & Aug 03 & NO & - & \\
\hline 14 & Jul 03 & NO & + & - & - & ND & ND & ND & Jul 31 & NO & - & \\
\hline 15 & Jun 25 & NO & + & - & - & Jul 10 & NO & - & Jul 24 & NO & - & \\
\hline 16 & Jun 30 & NO & + & - & - & Jul 14 & NO & - & Jul 28 & NO & - & \\
\hline 17 & Jun 26 & NO & + & - & - & Jul 10 & NO & - & Jul 24 & NO & - & \\
\hline 18 & Jun 30 & NO & + & - & - & Jul 14 & NO & - & Jul 28 & NO & - & \\
\hline 19 & Jul 04 & NO & + & - & - & Jul 21 & NO & - & Aug 04 & NO & - & \\
\hline 20 & Jun 26 & NO & + & - & - & Jul 10 & NO & - & Jul 24 & NO & - & \\
\hline 21 & Jun 26 & NO & + & - & - & Jul 10 & NO & - & Jul 24 & NO & - & \\
\hline 22 & Jul 03 & NO & + & - & - & Jul 17 & NO & - & Jul 31 & NO & - & \\
\hline 23 & Jun 30 & YES & + & - & - & Jul 15 & YES & - & ND & ND & ND & \\
\hline 24 & Jun 25 & NO & + & - & - & Jul 09 & NO & - & Jul 28 & NO & - & \\
\hline 25 & Jul 02 & NO & + & - & - & Jul 16 & NO & - & Aug 01 & NO & - & \\
\hline 26 & Jun 25 & YES & + & - & - & Jul 10 & NO & - & Jul 28 & NO & - & \\
\hline 27 & Jun 25 & NO & + & - & - & Jul 09 & NO & - & Jul 24 & NO & - & \\
\hline 28 & Jun 30 & $\mathrm{NO}$ & - & - & - & Jul 14 & YES & + & Jul 28 & $\mathrm{NO}$ & + & \multirow{21}{*}{ 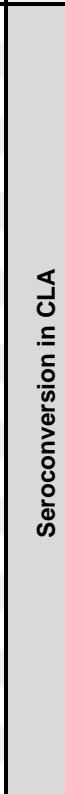 } \\
\hline 29 & Jun 26 & NO & - & - & - & Jul 10 & YES & + & Jul 25 & NO & + & \\
\hline 30 & Jun 26 & NO & - & - & - & Jul 13 & NO & + & Jul 24 & NO & + & \\
\hline 31 & Jun 30 & NO & - & - & - & Jul 15 & YES & + & Jul 30 & NO & + & \\
\hline 32 & Jun 25 & NO & - & - & - & Jul 13 & YES & + & Jul 23 & NO & + & \\
\hline 33 & Jul 03 & NO & - & - & - & Jul 17 & YES & + & Jul 31 & YES & + & \\
\hline 34 & Jul 03 & NO & - & - & - & Jul 17 & YES & + & Jul 31 & NO & + & \\
\hline 35 & Jun 26 & NO & - & - & - & Jul 15 & NO & + & Jul 24 & NO & + & \\
\hline 36 & Jul 03 & NO & - & - & - & Jul 17 & NO & + & Aug 03 & NO & + & \\
\hline 37 & Jun 25 & NO & - & - & - & Jul 09 & NO & - & Jul 27 & YES & + & \\
\hline 38 & Jul 03 & NO & - & - & - & Jul 17 & NO & - & Aug 10 & YES & + & \\
\hline 39 & Jun 30 & NO & - & - & - & Jul 14 & NO & - & Jul 30 & YES & + & \\
\hline 40 & Jul 03 & NO & - & - & - & Jul 17 & NO & - & Jul 31 & NO & + & \\
\hline 41 & Jun 25 & NO & - & - & - & Jul 09 & NO & - & Jul 28 & YES & + & \\
\hline 42 & Jul 03 & NO & - & - & - & Jul 17 & NO & - & Jul 31 & $\mathrm{NO}$ & + & \\
\hline 43 & Jul 01 & NO & - & - & - & Jul 15 & YES & - & Jul 31 & NO & + & \\
\hline 44 & Jun 30 & NO & - & - & - & Jul 17 & NO & - & Aug 08 & NO & + & \\
\hline 45 & Jun 26 & NO & - & - & - & ND & ND & ND & Jul 24 & NO & + & \\
\hline 46 & Jul 01 & NO & - & - & - & ND & ND & ND & Jul 29 & YES & + & \\
\hline 47 & Jul 03 & NO & - & - & - & ND & ND & ND & Aug 05 & YES & + & \\
\hline 48 & Jul 02 & YES & - & - & - & ND & ND & ND & Jul 31 & NO & + & \\
\hline
\end{tabular}

* Symptoms before sample. Symptoms included cough, runny nose, fever, diarrhea, shortness of breath, sneeze, headache, odynophagia, dysgeusia, anosmia. ND; not done. CLA; Chemiluminescence assay. LFA; Lateral Flow Assay. 
medRxiv preprint doi: https://doi.org/10.1101/2020.09.15.20195313; this version posted September 18, 2020. The copyright holder for this preprint (which was not certified by peer review) is the author/funder, who has granted medRxiv a license to display the preprint in perpetuity.

It is made available under a CC-BY-NC-ND 4.0 International license .

Table 2. Date of blood sample and date and result of SARS-CoV-2 specific PCR performed in the study volunteers with at least one antibody positive results at baseline.

\begin{tabular}{|c|c|c|c|c|c|c|c|c|c|c|}
\hline & \multicolumn{3}{|c|}{ Sample 1} & \multicolumn{3}{|c|}{ Sample 2} & \multicolumn{3}{|c|}{ Sample 3} & \\
\hline Volunteer & Date Abs & Date PCR & PCR & Date Abs & Date PCR & PCR & Date Abs & Date PCR & PCR & \\
\hline 1 & Jul 04 & ND & ND & Jul 21 & Jul 15 & - & Aug 05 & ND & ND & \\
\hline 2 & Jul 03 & Apr 23 & + & Jul 17 & ND & ND & Aug 01 & ND & ND & $\stackrel{\oplus}{.}$ \\
\hline 3 & Jun 25 & Apr 27 & - & Jul 09 & Jun 28 & - & Jul 23 & ND & ND & $\bar{\Phi}$ \\
\hline 4 & Jun 30 & ND & ND & Jul 16 & ND & ND & Jul 30 & ND & ND & $\tilde{m}$ \\
\hline 5 & Jul 01 & Mar 27 & - & Jul 15 & ND & ND & Jul 29 & ND & ND & $\pi$ \\
\hline 6 & Jul 04 & $\begin{array}{c}\text { Jul } 02 \\
\text { Jun } 10 \\
\text { Jun } 24\end{array}$ & $\begin{array}{l}- \\
+ \\
+\end{array}$ & Jul 18 & ND & ND & Aug 01 & ND & ND & 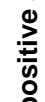 \\
\hline 7 & Jul 02 & $\begin{array}{l}\text { Mar } 22 \\
\text { Mar } 27\end{array}$ & - & Jul 16 & ND & ND & Jul 30 & ND & ND & $\stackrel{0}{4}$ \\
\hline 8 & Jun 30 & ND & ND & Jul 14 & ND & ND & Jul 28 & ND & ND & \\
\hline 9 & Jun 27 & ND & ND & Jul 11 & ND & ND & Jul 25 & ND & ND & \\
\hline 10 & Jun 25 & ND & ND & Jul 10 & Jun 27 & - & Jul 24 & ND & ND & \\
\hline 11 & Jul 03 & ND & ND & Jul 17 & Jul 07 & - & Jul 31 & ND & ND & \\
\hline 12 & Jun 25 & ND & ND & Jul 09 & Jun 28 & - & Jul 23 & ND & ND & \\
\hline 13 & Jul 04 & Jun 23 & - & Jul 21 & ND & ND & Aug 03 & ND & ND & \\
\hline 14 & Jul 03 & ND & ND & ND & Jul 06 & - & Jul 31 & ND & ND & $\stackrel{\Xi}{=}$ \\
\hline 15 & Jun 25 & ND & ND & Jul 10 & Jun 27 & - & Jul 24 & ND & ND & $\bar{\Phi}$ \\
\hline 16 & Jun 30 & ND & ND & Jul 14 & Jul 02 & - & Jul 28 & ND & ND & $\mathbb{m}$ \\
\hline 17 & Jun 26 & ND & ND & Jul 10 & Jun 27 & - & Jul 24 & ND & ND & $\ddot{\sigma}$ \\
\hline 18 & Jun 30 & ND & ND & Jul 14 & Jul 02 & - & Jul 28 & ND & ND & $\$$ \\
\hline 19 & Jul 04 & ND & ND & Jul 21 & Jul 08 & - & Aug 04 & ND & ND & $\geqq$ \\
\hline 20 & Jun 26 & ND & ND & Jul 10 & ND & ND & Jul 24 & ND & ND & \& \\
\hline 21 & Jun 26 & ND & ND & Jul 10 & Jun 27 & - & Jul 24 & ND & ND & $\frac{0}{4}$ \\
\hline 22 & Jul 03 & ND & ND & Jul 17 & Jul 08 & - & Jul 31 & ND & ND & ए \\
\hline 23 & Jun 30 & ND & ND & Jul 15 & Jul 02 & - & ND & ND & ND & \\
\hline 24 & Jun 25 & ND & ND & Jul 09 & Jun 27 & - & Jul 28 & ND & ND & \\
\hline 25 & Jul 02 & ND & ND & Jul 16 & Jul 05 & - & Aug 01 & ND & ND & \\
\hline 26 & Jun 25 & ND & ND & Jul 10 & Jun 29 & - & Jul 28 & ND & ND & \\
\hline 27 & Jun 25 & ND & ND & Jul 09 & Jul 03 & - & Jul 24 & ND & ND & \\
\hline 28 & Jun 30 & ND & ND & Jul 14 & ND & ND & Jul 28 & Jul 14 & + & \\
\hline 29 & Jun 26 & ND & ND & Jul 10 & Jun 30 & - & Jul 25 & ND & ND & \\
\hline 30 & Jun 26 & ND & ND & Jul 13 & ND & ND & Jul 24 & ND & ND & \\
\hline 31 & Jun 30 & ND & ND & Jul 15 & Jul 02 & + & Jul 30 & ND & ND & \\
\hline 32 & Jun 25 & ND & ND & Jul 13 & $\begin{array}{c}\text { Jun } 28 \\
\text { Jul } 09\end{array}$ & + & Jul 23 & ND & ND & \\
\hline 33 & Jul 03 & ND & ND & Jul 17 & $\begin{array}{c}\text { Jul } 3 \\
\text { Jul } 14\end{array}$ & $\begin{array}{l}+ \\
-\end{array}$ & Jul 31 & ND & ND & $\varangle$ \\
\hline 34 & Jul 03 & ND & ND & Jul 17 & Jul 04 & + & Jul 31 & ND & ND & $\vec{U}$ \\
\hline 35 & Jun 26 & ND & ND & Jul 15 & ND & ND & Jul 24 & Jul $17^{*}$ & - & $\subseteq$ \\
\hline 36 & Jul 03 & ND & ND & Jul 17 & ND & ND & Aug 03 & ND & ND & 으 \\
\hline 37 & Jun 25 & ND & ND & Jul 09 & ND & ND & Jul 27 & Jul 16 & + & कू \\
\hline 38 & Jul 03 & ND & ND & Jul 17 & ND & ND & Aug 10 & Jul 20 & + & 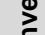 \\
\hline 39 & Jun 30 & ND & ND & Jul 14 & ND & ND & Jul 30 & Jul 30 & + & 동 \\
\hline 40 & Jul 03 & ND & ND & Jul 17 & ND & ND & Jul 31 & Aug 03 & + & 온 \\
\hline 41 & Jun 25 & ND & ND & Jul 09 & ND & ND & Jul 28 & Jul 14 & + & ळ \\
\hline 42 & Jul 03 & ND & ND & Jul 17 & ND & ND & Jul 31 & Aug 03* & - & \\
\hline 43 & Jul 01 & ND & ND & Jul 15 & ND & ND & Jul 31 & Jul 16 & + & \\
\hline 44 & Jun 30 & ND & ND & Jul 17 & ND & ND & Aug 08 & Jul 24 & + & \\
\hline 45 & Jun 26 & ND & ND & ND & Jul 08 & - & Jul 24 & ND & ND & \\
\hline 46 & Jul 01 & ND & ND & ND & ND & ND & Jul 29 & Jul 07 & + & \\
\hline 47 & Jul 03 & ND & ND & ND & ND & ND & Aug 05 & Jul 16 & + & \\
\hline 48 & Jul 02 & ND & ND & ND & Jul 03* & + & ND & ND & ND & \\
\hline
\end{tabular}

Shown are results (PCR) and dates (Date PCR) in which SARS-CoV-PCR was performed prior to each one of the three blood study samples (Date Abs). ND; not done. PCR were not part of the study protocol 
medRxiv preprint doi: https://doi.org/10.1101/2020.09.15.20195313; this version posted September 18, 2020. The copyright holder for this preprint (which was not certified by peer review) is the author/funder, who has granted medRxiv a license to display the preprint in perpetuity.

It is made available under a CC-BY-NC-ND 4.0 International license .

but were performed in our Clinical Laboratory from nasopharyngeal aspirates using the VIASURE RealTime PCR Detection Kit plates (CerTest BIOTEC, Zaragoza, Spain). ${ }^{*}$ PCR reported by participants to have been performed outside of our Clinical Laboratory. 
medRxiv preprint doi: https://doi.org/10.1101/2020.09.15.20195313; this version posted September 18, 2020. The copyright holder for this preprint (which was not certified by peer review) is the author/funder, who has granted medRxiv a license to display the preprint in perpetuity.

It is made available under a CC-BY-NC-ND 4.0 International license .

Table 3. Comparison of demographics and risk factors of CLA IgG negative and positive patients

\begin{tabular}{|c|c|c|c|}
\hline Characteristic & $\begin{array}{l}\text { Negative } \\
(n=322)\end{array}$ & $\begin{array}{l}\text { Positive } \\
(n=29)\end{array}$ & OR $(95 \% \mathrm{CI})$ \\
\hline \multicolumn{4}{|l|}{ Demographics } \\
\hline Age, years; Median (IQR) & $\begin{array}{c}31.5(27.5- \\
38.6)\end{array}$ & $29.4(26.9-37)$ & $\begin{array}{c}0.98(0.94- \\
1.03)\end{array}$ \\
\hline \multicolumn{4}{|l|}{ Sex; n (\%) } \\
\hline Women & $192(59.6)$ & $14(48.3)$ & Reference \\
\hline Men & $130(40.4)$ & $15(51.7)$ & $\begin{array}{c}1.58(0.74- \\
3.39)\end{array}$ \\
\hline \multicolumn{4}{|l|}{ Mode of transport; $n(\%)$} \\
\hline Public transport & $7(2.2)$ & $1(3.4)$ & Reference \\
\hline Car/moto & $256(79.5)$ & $21(72.4)$ & $\begin{array}{c}0.57(0.07- \\
4.89)\end{array}$ \\
\hline Walking/Bycicle & $59(18.3)$ & $7(24.1)$ & $\begin{array}{c}0.83(0.09- \\
7.78)\end{array}$ \\
\hline \multicolumn{4}{|l|}{ Service; n (\%) } \\
\hline Emergencies & $66(20.5)$ & $8(27.6)$ & Reference \\
\hline $\mathrm{ICU}$ & $11(3.4)$ & $1(3.4)$ & $0.75(0.09-6.6)$ \\
\hline Outpatient consultation & $60(18.6)$ & $5(17.2)$ & $\begin{array}{c}0.69(0.21- \\
2.22)\end{array}$ \\
\hline Other & $185(57.5)$ & $15(51.7)$ & $\begin{array}{c}0.67(0.27- \\
1.65)\end{array}$ \\
\hline \multicolumn{4}{|l|}{ Occupation; n (\%) } \\
\hline Healthcare worker in training & $167(51.9)$ & $20(69)$ & Reference \\
\hline Healthcare worker & $155(48.1)$ & $9(31)$ & $0.48(0.21-1.1)$ \\
\hline \multicolumn{4}{|l|}{ Risk Factors } \\
\hline \multicolumn{4}{|l|}{ Obesity; n (\%) } \\
\hline No & $306(95)$ & $27(93.1)$ & Reference \\
\hline Yes & $16(5)$ & $2(6.9)$ & $\begin{array}{c}1.42(0.31- \\
6.49)\end{array}$ \\
\hline \multicolumn{4}{|l|}{ Smoking behavior; $\mathrm{n}(\%)$} \\
\hline No & $301(93.5)$ & $26(89.7)$ & Reference \\
\hline Yes & $21(6.5)$ & $3(10.3)$ & $\begin{array}{c}1.65(0.46- \\
5.91)\end{array}$ \\
\hline \multicolumn{4}{|l|}{ Diabetes diagnosis; n (\%) } \\
\hline No & $319(99.1)$ & $28(96.6)$ & Reference \\
\hline Yes & $3(0.9)$ & $1(3.4)$ & $\begin{array}{c}3.8(0.38- \\
37.72)\end{array}$ \\
\hline \multicolumn{4}{|l|}{ Hypertension diagnosis; n (\%) } \\
\hline No & $306(95)$ & $26(89.7)$ & Reference \\
\hline Yes & $16(5)$ & $3(10.3)$ & $2.21(0.6-8.07)$ \\
\hline
\end{tabular}

Symptoms before recruitment; $n$ 
(\%)

$\begin{array}{lccc}\text { No } & 255(79.2) & 24(82.8) & \text { Reference } \\ \text { Yes } & 67(20.8) & 5(17.2) & 0.79(0.29- \\ & & 2.16)\end{array}$

COVID-19 exposure

Close contact with COVID-19 patients; $\mathrm{n}(\%)$

No

Yes

Not known

Contact with body fluids; $\mathrm{n}(\%)$

No

Yes

Not known

Use of Personal Protection

Elements; $\mathrm{n}(\%)$

No

Yes, complete per protocol

Yes, incomplete
76 (23.6)

$180(55.9)$

$66(20.5)$

194 (60.2)

107 (33.2)

$21(6.5)$

$1(0.3)$

294 (91.3)

27 (8.4)
7 (24.1)

17 (58.6)

5 (17.2)

13 (44.8)

13 (44.8)

3 (10.3)

$0(0)$

27 (93.1)

2 (6.9)
Reference

Reference

$1.03(0.41$ -

2.57)

$0.82(0.25-$

2.71)

Reference

1.81 (0.81 -

4.05)

$2.13(0.56-$

8.09)

$1.24(0.28$ - 5.5) 
medRxiv preprint doi: https://doi.org/10.1101/2020.09.15.20195313; this version posted September 18, 2020. The copyright holder for this preprint (which was not certified by peer review) is the author/funder, who has granted medRxiv a license to display the preprint in perpetuity.

It is made available under a CC-BY-NC-ND 4.0 International license .

Table 4. Concordance between CLA IgG and LFA IgG, LFA IgM, and ELFA IgM

\begin{tabular}{|c|c|c|c|c|}
\hline & & \multicolumn{2}{|c|}{ CLA IgG } \\
\hline & Cohen's Kappa & & + & - \\
\hline LFA IgG & $0.664695 \% \mathrm{Cl}(0.5541-0.7751)$ & + & 33 & 11 \\
\cline { 3 - 5 } & & - & 20 & 956 \\
\hline LFA IgM & $0.366395 \% \mathrm{Cl}(0.2387-0.4939)$ & + & 19 & 24 \\
\cline { 3 - 5 } & & - & 34 & 943 \\
\hline ELFA IgM & $0.620795 \% \mathrm{Cl}(0.5034-0.7380)$ & + & 30 & 13 \\
\cline { 3 - 5 } & & - & 21 & 941 \\
\hline
\end{tabular}

${ }^{*}$ Fifteen samples were read as invalid by ELFA and three individuals did not authorize for their sample to be used after the initial test. 
Table 5.Concordance between ELFA IgM and LFA IgM

\begin{tabular}{|c|c|c|c|c|}
\hline & & \multicolumn{3}{|c|}{ ELFA IgM } \\
\hline & Cohen's Kappa & & + & - \\
\hline \multirow{2}{*}{ LFA IgM } & $0.246895 \%$ Cl $(0.1191-0.3745)$ & + & 12 & 31 \\
\cline { 3 - 5 } & & - & 31 & 931 \\
\hline
\end{tabular}

${ }^{*}$ Fifteen samples were read as invalid by ELFA.

\section{References:}

[1] C.F. Houlihan, N. Vora, T. Byrne, D. Lewer, G. Kelly, J. Heaney, S. Gandhi, M.J. Spyer, Rupert Beale, P. Cherepanov, D. Moore, R. Gilson, S. Gamblin, G.

Kassiotis, L.E. McCoy, C. Swanton, A. Hayward, E. Nastouli, Pandemic peak SARS-CoV-2 infection and seroconversion rates in London frontline health-care workers, Lancet. 396 (2020) e6-e7. https://doi.org/10.1016/S01406736(20)31484-7.

[2] S.F. Malfertheiner, S. Brandstetter, S. Roth, S. Harner, H. Buntrock-Döpke, A.A. Toncheva, N. Borchers, S.H. Rudolf Gruber, Andreas Ambrosch, Michael Kabesch, Immune response to SARS-CoV-2 in health care workers following a COVID-19 outbreak: a prospective longitudinal study, J. Clin. Virol. (2020). https://doi.org/10.1016/j.jcv.2020.104575.

[3] M. Comar, M. Brumat, M.P. Concas, G. Argentini, L. Bicego, R. Bottega, P. Carli, A. Cassone, E. Catamo, S. Morassut, A. Morgan, G. Pelliccione, V. Petix, G. Ragusa, COVID-19 experience $\square$ : first Italian survey on healthcare staff members from a Mother-Child Research Hospital using combined molecular and rapid immunoassays test., MedRxiv. (2020). 
[4] M.T. Sandri, E. Azzolini, V. Torri, S. Carloni, M. Tedeschi, C. Massimo, A. Mantovani, M. Rescigno, IgG serology in health care and administrative staff populations from 7 hospitals representative of different exposures to SARS-CoV-2 in Lombardy, Italy, MedRxiv. (2020).

[5] M. Mansour, E. Leven, K. Muellers, K. Stone, D.R. Mendu, A. Wajnberg, Prevalence of SARS-CoV-2 Antibodies Among Healthcare Workers at a Tertiary Academic Hospital in New York City, J. Gen. Intern. Med. 35 (2020) 2485-2486. https://doi.org/10.1007/s11606-020-05926-8.

[6] S.J.C. Pallett, M. Rayment, A. Patel, S.A.M. Fitzgerald-Smith, S.J. Denny, E. Charani, A.L. Mai, K.C. Gilmour, J. Hatcher, C. Scott, P. Randell, N. Mughal, R. Jones, L.S.P. Moore, G.W. Davies, Point-of-care serological assays for delayed SARS-CoV-2 case identification among health-care workers in the UK: a prospective multicentre cohort study, Lancet Respir. Med. 2600 (2020) 1-10. https://doi.org/10.1016/s2213-2600(20)30315-5.

[7] A.M. Shields, S.E. Faustini, M. Perez-Toledo, S. Jossi, E. Aldera, J.A. D., S. AlTaei, C. Backhouse, A. Bosworth, L. Dunbar, D. Ebanks, B. Emmanuel, J. Grey, I.M. Kidd, G. McGinnell, D. McLoughlin, G. Morley, J. O’Neill, D. Papakonstantinou, O. Pickles, C. Poxon, M. Richter, E. Walker, K. Wanigasooriya, Y. Watanabe, C. Whalley, A.E. Zielinska, M. Crispin, D.C. Wraith, A.D. Beggs, A.F. Cunningham, M.T. Drayson, A.G. Richter, SARS-CoV-2 seroconversion in health care workers, MedRxiv Prepr. (2020). https://doi.org/https://doi.org/10.1101/2020.05.18.20105197.

[8] D.S. Hains, A.L. Schwaderer, A.E. Carroll, M.C. Starr, A.C. Wilson, F. Amanat, F. 
Krammer, Asymptomatic Seroconversion of Immunoglobulins to SARS-CoV-2 in a Pediatric Dialysis Unit, JAMA. (2020). https://doi.org/10.1001/jama.2020.8438.

[9] World Health Organization Coronavirus disease (COVID-19), 2020. https://doi.org/10.1097/jcn.0000000000000710.

[10] Epidemiological Highlights - Region of the Americas, PAHO Epidemiol. Updat. Coronavirus Dis. (2020) 1-22.

https://www.paho.org/en/documents/epidemiological-update-coronavirus-diseasecovid-19-26-august-2020.

[11] M.F. Silveira, A.J.D. Barros, B.L. Horta, L.C. Pellanda, G.D. Victora, O.A. Dellagostin, C.J. Struchiner, M.N. Burattini, A.R.M. Valim, E.M. Berlezi, J.M. Mesa, M.L.R. Ikeda, M.A. Mesenburg, M. Mantesso, M.M. Dall'Agnol, R.A. Bittencourt, F.P. Hartwig, A.M.B. Menezes, F.C. Barros, P.C. Hallal, C.G. Victora, Population-based surveys of antibodies against SARS-CoV-2 in Southern Brazil, Nat. Med. 26 (2020) 1196-1199. https://doi.org/10.1038/s41591-020-0992-3.

[12] S. Figar, V. Pagotto, L. Luna, J. Salto, M.W. Manslau, A.S. Mistchenko, A. Gamarnik, A.M.G. Saldaño, F.G. Bernaldo de Quiroz, Community-level SARSCoV-2 Seroprevalence Survey in urban slum dwellers of Buenos Aires City, Argentina: a participatory research., MedRxiv. (2020).

[13] J.P. Torres, C. Piñera, V. De La Maza, A.J. Lagomarcino, D. Simian, B. Torres, C. Urquidi, M.T. Valenzuela, M. O'Ryan, SARS-CoV-2 antibody prevalence in blood in a large school community subject to a Covid-19 outbreak: a cross-sectional study, Clin. Infect. Dis. (2020). https://doi.org/https://doi.org/10.1093/cid/ciaa955.

[14] R.K. Arora, A. Joseph, J. Van Wyk, S. Rocco, A. Atmaja, E. May, T. Yan, N. 
Bobrovitz, J. Chevrier, M.P. Cheng, T. Williamson, D.L. Buckeridge, SeroTracker: a global SARS-CoV-2 seroprevalence dashboard, Lancet Infect. Dis. 3099 (2020) 9-10. https://doi.org/10.1016/s1473-3099(20)30631-9.

[15] C. Ismael, P. Ismael, C. Marchon, M. Sergio, V. De Melo, Universal Screening of SARS-CoV-2 of Oncology Healthcare Work- ers - a Brazilian experience, Scielo Prepr. (2020). https://doi.org/10.1590/SciELOPreprints.293.

[16] P.A. Harris, R. Taylor, R. Thielke, J. Payne, N. Gonzalez, J.G. Conde, Research electronic data capture (REDCap)-A metadata-driven methodology and workflow process for providing translational research informatics support, J. Biomed. Inform. 42 (2009) 377-381. https://doi.org/10.1016/j.jbi.2008.08.010.

[17] S. Van den Fleur Wolff, Hafid Dahma, Cécile Duterme, I. Wijngaert, Olivier Vandenberg, Frédéric Cotton, Montesinos, Monitoring antibody response following SARS-CoV-2 infection: Diagnostic efficiency of four automated immunoassays, Diagnostic Microbiol. Infect. Dis. (2020). https://doi.org/10.1016/j.bbadis.2020.165686.

[18] M.L. McHugh, Interrater reliability: the kappa statistic, Biochem. Medica. 22 (2012) 276-282. https://pubmed.ncbi.nlm.nih.gov/23092060.

[19] L. Rivett, S. Sridhar, D. Sparkes, M. Routledge, N.K. Jones, S. Forrest, J. Young, J. Pereira-Dias, W.L. Hamilton, M. Ferris, M.E. Torok, L. Meredith, M. Curran, S. Fuller, A. Chaudhry, A. Shaw, R.J. Samworth, J.R. Bradley, G. Dougan, K.G.C. Smith, P.J. Lehner, N.J. Matheson, G. Wright, I. Goodfellow, S. Baker, M.P. Weekes, Screening of healthcare workers for SARS-CoV-2 highlights the role of asymptomatic carriage in COVID-19 transmission, Elife. 9 (2020) 1-20. 
https://doi.org/10.7554/eLife.58728.

[20] A.L. Wyllie, J. Fournier, A. Casanovas-Massana, M. Campbell, M. Tokuyama, P. Vijayakumar, B. Geng, M.C. Muenker, A. Moore, C. Vogels, M. Petrone, I. Ott, P. Lu, A. Lu-Culligan, J. Klein, A. Venkataraman, R. Earnest, M. Simonov, R. Datta, R. Handoko, N. Naushad, L. Sewanan, J. Valdez, E. White, S. Lapidus, C. Kalinich, X. Jiang, D. Kim, E. Kudo, M. Linehan, T. Mao, M. Moriyama, J.E. Oh, A. Park, J. Silva, E. Song, T. Takahashi, M. Taura, O.-E. Weizman, P. Wong, Y. Yang, S. Bermejo, C. Odio, S. Omer, C. Dela Cruz, S. Farhadian, R. Martinello, A. Iwasaki, N. Grubaugh, A. Ko, Saliva is more sensitive for SARS-CoV-2 detection in COVID-19 patients than nasopharyngeal swabs, (2020). https://doi.org/10.1101/2020.04.16.20067835.

[21] M.M. Arons, K.M. Hatfield, S.C. Reddy, A. Kimball, A. James, J.R. Jacobs, J. Taylor, K. Spicer, A.C. Bardossy, L.P. Oakley, S. Tanwar, J.W. Dyal, J. Harney, Z. Chisty, J.M. Bell, M. Methner, P. Paul, C.M. Carlson, H.P. Mclaughlin, N. Thornburg, S. Tong, A. Tamin, Y. Tao, A. Uehara, J. Harcourt, S. Clark, C.B. Smith, L.C. Page, M. Kay, J. Lewis, P. Montgomery, N.D. Stone, T.A. Clark, M.A. Honein, Presymptomatic SARS-CoV-2 Infections and Transmission in a Skilled Nursing Facility, N. Engl. J. Med. (2020) 1-10. https://doi.org/10.1056/NEJMoa2008457.

[22] C. Kenyon, The prominence of asymptomatic superspreaders in transmission mean universal face masking should be part of COVID-19 de-escalation strategies, Int. J. Infect. Dis. 97 (2020) 21-22. https://doi.org/10.1016/j.ijid.2020.05.102. 
[23] A. Bryan, G. Pepper, M.H. Wener, S.L. Fink, C. Morishima, A. Chaudhary, K.R. Jerome, P.C. Mathias, A.L. Greninger, Performance Characteristics of the Abbott Architect SARS-CoV-2 IgG Assay and Seroprevalence in Boise, Idaho, J. Clin. Microbiol. (2020). https://doi.org/10.1128/JCM.00941-20.

[24] F. Hamilton, P. Muir, M. Attwood, A. Noel, B. Vipond, R. Hopes, E. Moran, N. Maskell, D. Warwick, M. Albur, J. Turner, A.P. MacGowan, D.T. Arnold, Kinetics and performance of the Abbott Architect SARS-CoV-2 IgG antibody assay, MedRxiv. (2020) 2020.07.03.20145722.

https://doi.org/10.1101/2020.07.03.20145722.

[25] S. Meschi, F. Colavita, L. Bordi, G. Matusali, D. Lapa, A. Amendola, F. Vairo, G. Ippolito, M.R. Capobianchi, C. Castilletti, Performance evaluation of Abbott ARCHITECT SARS-CoV-2 IgG immunoassay in comparison with indirect immunofluorescence and virus microneutralization test, J. Clin. Virol. 129 (2020) 104539. https://doi.org/10.1016/j.jcv.2020.104539.

[26] K.J. Paiva, R.D. Grisson, P.A. Chan, J.R. Lonks, J. King, R. Huard, D.L. PytelParenteau, G.H. Nam, E. Yakirevich, S. Lu, Validation and Performance 1 Comparison of Three SARS-CoV-2 Antibody Assays, BioRxiv. (2020). https://doi.org/10.1017/CBO9781107415324.004. 


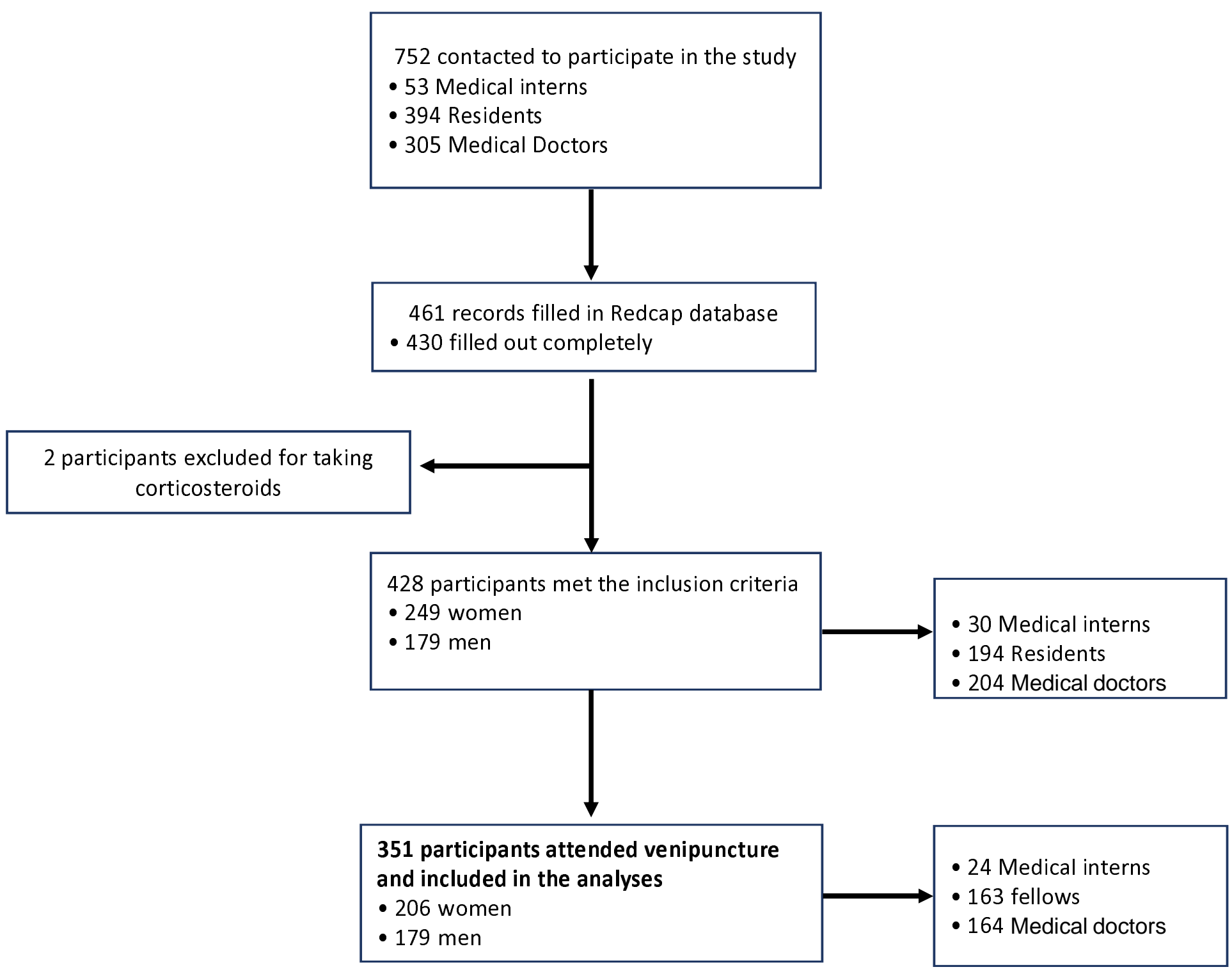




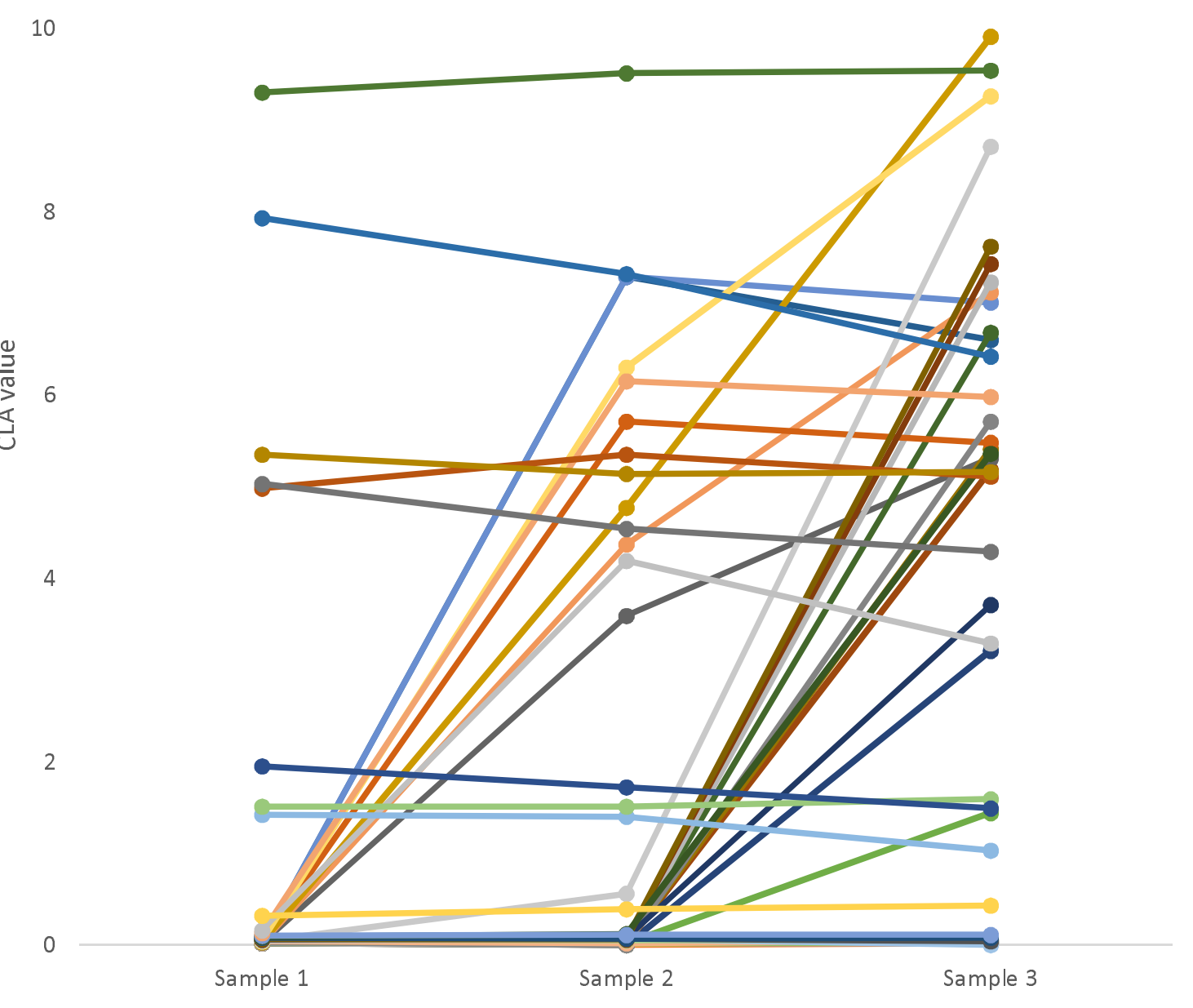

